\title{
География русской квир-поэзии: Польша как место встречи традиции и скандала
}

\author{
Geography of Russian Queer Poetry: Poland as Space Where Tradition and Scandal Meet
}

\begin{abstract}
The article focuses on the issue of Poland as a specific artistic space in queer poetry in Russia of the 90s and 2000s. Drawing on the creative work of Alexandr Anashevich, Yaroslav Mogutin, Alexandr Ilyanen and Ilya Danishevskiy, it reveals the connection between traditional narratives present in the Soviet official and unofficial, underground literature and new perceptions of gender. While partly sharing in "gender anxiety," Poland is, nevertheless, considered a commonplace setting in queer poetry practices and performances on account of its unreliable, limitrophe, "threshold" nature for Russian-speaking recipients.
\end{abstract}

Keywords: queer studies, gay poetry, LGBT, Poland, imaginative geography, border studies

Ключевые слова: Квир исследования, гей-поэзия, ЛГБТ, Польша, образная география, исследования границ

Geografia rosyjskiej poezji queer: Polska jako miejsce spotkań skandalu i tradycji

Streszczenie: Artykuł koncentruje się na problematyce Polski jako specyficznej przestrzeni artystycznej w poezji, wpisującej się w dyskurs gay i queer w Rosji lat 90. i pierwszej dekady XXI wieku. Na materiale pracy twórczej Aleksandra Anaszewicza, Jarosława Mogutina, Aleksandra Ilianena i Ilii Daniszewskiego został ujawniony związek między tradycyjnymi narracjami radzieckiej oficjalnej i nieoficjalnej literatury oraz nowe postrzeganie pojęcia płci w kontekście geopoetyki. Polska, choć częściowo podzielająca poczucie „lęku przed płcią”, uważana jest za popularne miejsce w queerowych praktykach i przedstawieniach poetyckich z powodu jej istotnej niewiarygodnej, ,progowej”, „granicznej” natury dla rosyjskojęzycznych odbiorców.

Słowa kluczowe: teoria queer, poezja gejowska, LGBT, Polska, geografia wyobrażeniowa, teoria granic 
Говорить о квир-исследованиях в России, по меткому замечанию Терезе Гарстенауэр, «не означает рассказывать историю успеха» ${ }^{1}$. Данная область культуры и науки - настоящая terra incognita: в том числе и в литературоведении действительно небольшое количество исследовательских работ посвящены непосредственно поэтике и проблематике художественных произведений, создаваемых в данной нише. Табуирование темы ЛГБТ-сообществ в России, гомофобные и радикально ксенофобные настроения, существующие в медийном и даже порой научном дискурсе ${ }^{2}$, а также Федеральный закон 2013 года «О запрете пропаганды нетрадиционных сексуальных отношений среди несовершеннолетних», который de facto делает открытую и объективную дискуссию о квир-идентичности и художественных особенностях квирлитературы практически невозможной, маргинализируют целое научное направление. В литературоведении все еще относительно безопасно говорить о гендерных исследованиях в контексте женской прозы и феминистского дискурса, однако изучение маскулинной природы и ее сексуальных аспектов в искусстве нередко встречает сопротивление в консервативных научных кругах - вплоть до полного отрицания данной оптики. Российская квир-культура во всем ее многообразии - предмет изучения разных наук: в первую очередь, социологии, педагогики, психологии, юриспруденции и антропологии, - а основной проблемой для исследования, научным «мэйнстримом» стало взаимоотношение ЛГБТ-сообществ и государства. Попытки говорить о непосредственно эстетической составляющей квир-культуры и обнаружения общего описательного языка ее репрезентантов, создание метатекстов об искусстве слова отошли на периферию научного познания.

Практически единственное на данный момент исключение в данном контексте составляет интердисциплинарный сборник статей Нa nерепутье: методология, теория и практика ЛГБТ и квир-исследований, изданный в 2014 году с пометкой 18+ по результатам одноименной конференции, которая проходила в Санкт-Петербурге 23-25 октября 2013 года уже после принятия закона «О запрете пропаганды нетрадиционных сексуальных отношений среди несовершеннолетних». В книге представлены квир-исследования социологов, антропологов, юристов, ЛГБТ-активистов, а также примеры литературоведческих исследований произведений Евгения Харитонова и Геннадия Трифонова, с точки зрения гомосексуальной оптики ${ }^{3}$, выявления гендерной специфики русскоязычных фанфиков, в которых изображение представителей ЛГБТ-сообщества является устойчивым «законом

${ }^{1}$ Т. Гарстенауэр, Гендерные и квир-исследования в России, «Социология власти» 2018, № 1 , c. 160 .

${ }^{2}$ См.: Н.А. Комлева, Переформатирование гендера как проявление «мягкой силь»" в геополитических прочессах, «Дискурс-Пи» 2015, № 12, с. 129-145; С.В. Устинкин, Е.К. Рудакова, Д.С. Эминов, Гендерные стратегии «мягкой силь»» НПО как инструмент переформатирования культурного кода общества и государства в России, «Власть» 2016, № 1, с. 5-15 и др.

${ }^{3}$ К. Мосс, Воплощение гомосексуальности в работах Евгения Харитонова и Геннадия Трифонова [в:] На перепутье: методология, теория и практика ЛГБТ и квир-исследований, Санкт-Петербург 2014, с. 191-201. 
жанра» ${ }^{4}$, и историко-литературного изучения содержательного наполнения журнала «Остров» и его Литературных приложений с 1999 по 2013 год, ориентированного на лесбийского аудиторию 5 .

Кроме этого, Дмитрий Кузьмин, поэт, один из основателей проекта «Вавилон», писатель и критик, исследует русские гей- и квир-дискурсы в рамках гранта Типология субъекта в русской поэзии 1990-2010-х.

Особенно интересной проблемой представляется анализ геопоэтической структуры квир-поэзии, возникшей в постсоветский период, ведь при существующем в современном российском обществе подходе ко всему со знаком queer как к отступлению от нормы, чему-то неестественному и извращенному, скандальному и эпатажному, совершенно упускается из внимания глубокий традиционализм этих текстов, определенный содержательный консерватизм, существующий на онтологическом уровне и черпающий вдохновение как в классической русской литературе, так и в советском официальном и неофициальном поэтических дискурсах.

Геокультура Польши в данном контексте, служившая общим культурным кодом нескольких поколений советской интеллигенции, начиная с хрущевской оттепели и вплоть до конца существования $\mathrm{CCCP}^{6}$, несомненно, представляет особый интерес для исследователя. Стоит подчеркнуть, что с распадом Советского Союза значимость Польского текста для русской культуры (как высокой, так и массовой) постепенно уходит, даже в какой-то степени маргинализируется. Художественное пространство Польши в сознании русскоязычного реципиента после 1991 года существует исключительно на периферии ментальной карты, вытесненное после открытия границ образами «более привлекательной» Западной Европы или экзотикой далёких стран, однако воспоминание о Польше, ее «мерцающие» значения, традиционные «фоновые» коннотации все ещё проявляются в художественных текстах направлений, в основном, маргинализированных обществом или осознанно контр-культурных ${ }^{7}$.

4 Е. Некрасова, Гомосексуальность как прием: гендерная специифика русскоязычного фанфика [в:] На перепутье..., ор. cit., с. 202-219.

5 Л. Королева, Контент-анализ журнала «Остров» и Литературных приложений как анализ смыслового пространства жизни лесбиянок в России в период с 1999 по 2013 г. [в:] На nерепутье..., ор. cit., с. 220-228.

${ }^{6}$ О Польском тексте советской официальной и неофициальной культуры см.: С. Вдовин, Польские мотивы в поэзии Окуджавы, Высочякого, Галича [в:] Окуджава. Проблемы поэтики и текстологии, ред. И. Ришина, Москва 2002, с. 5-24; В. Хорев, Польша и поляки глазами русских литераторов, Москва 2004; K. Vorontsova, Польский текст в поэзии Бориса Слуиякого: между идеологией и авторской позицией, «Przegląd Rusycystyczny» 2017, nr 3, c. 5-30; eadem, Польша в поэзии московских концептуалистов: деконструкция культурных мифов [в:] Współczesne badania nad folklorem i literaturą rosyjską: 30 lat toruńskiej rusycystyki, red. B. Żejmo, I. Rzepnikowska, Toruń 2017, с. 237-253 и др.

7 Ср.: Польша занимает заметную нишу в рок-поэзии 90-х и 2000-х: «В Польше - инфляция, в Латвии - Рига» (гр. Сплин, Урок географии), «Где моя родина, в кармане у Польши, / в кармане у Польши, за воротом Франции» (гр. Ночные снайперы, Земляничная), «Слезы, нервы, любовь / и стрелки в Польше» (Земфира, Искала) и т.д. В приведенных примерах заметна общая патографическая составляющая художественного пространства страны, которая упоминается 
Данная статья - попытка ответить на вопрос о специфическом значении Польского текста для русской квир-культуры, а также проблемах восприятия предшествующей традиции и эволюции отдельных ее аспектов. Материалом исследования служат поэтические произведения Александра Анашевича, Ярослава Могутина, Александра Ильянена и Ильи Данишевского, появившиеся в период 1990-2010-х годов, демонстрирующие различные аспекты польского художественного пространства в рамках маргинализированных и стигматизированных российским обществом форм чувствительности, сексуальности и гендера.

Каждый из упомянутых поэтов создает персональную вселенную с уникальными знаковыми странами и ключевыми топонимами, обусловленными геобиографическими обстоятельствами, пресловутой «тоской по мировой культуре» и личными предпочтениями, однако именно Польша является неким «общим местом», точкой притяжения, особенным художественным пространством, в границах которого удобно разворачивать лирические сюжеты о постижении себя и своей внутренней природы.

Сильнее других очарован предшествующим Польским текстом воронежский поэт, журналист и драматург, «самый гендерно-рефлексирующий автор поколения 1990-х» ${ }^{8}$ Александр Анашевич (настоящая фамилия - Яковлев), представитель группы авторов, связанных с проектом «Вавилон»: Польша возникает практически в каждой его книге стихов, эксплицитно и, более того, становится функциональным полем для разыгрывания внутренних и внешних конфликтов. Возможно, эта частотность связана с тем, что именно в творчестве «воронежского Кальдерона» ${ }^{9}$ наиболее ощутим синтез советской литературной традиции с инновационным подходом к пространству и телесности: через фольклорный раёк и архетипические культурные образы к постмодернистской чувствительности уровня Кэмпа в определении Сьюзан Зонтаг ${ }^{10}$. Очень многие тексты Анашевича написаны о женщине, от имени женщины или от лица мужчины в костюме женщины: трансвестита в перьях, паяца, шута из площадного балаганчика, актера театра кабуки. Как отмечает в послесловии к книге Столько ловушек Дмитрий Соколов: «Поэт в России не больше, чем поэт, а меньше, чем баба. Так что, Боже мой, неужели Анашевич - первая в русской литературе Ярославна» ${ }^{11}$. Подспудная скандальность этой позы вызывает раздражение и предубеждение ряда критиков, творчество поэта называющих не иначе, как «гермафродитизм от „Вавилона”», и пейоративно маркирующих эти тексты как «арт-брэнд свал-

каждый раз для маркирования кризисных моментов жизни лирического субъекта, артикулирующего свою ненормальность, анти-консюмеризм и противопоставленность добропорядочным членам общества. Данная тема, несомненно, требует отдельного анализа и исследования на более обширном материале.

8 А. Чанцев, Литература 2.0: Статьи о книгах, Москва 2011, с. 296.

9 О. Дарк, Кальдерон из Воронежа. Из цикла «Венок портретов современной русской поэзии», «Русский журнал» 2003, http://old.russ.ru/krug/20030616_od.html (доступ: 1.01.2019).

10 S. Sontag, Notes on “Camp”, «Partisan Review» 1964, No. 31 (4), c. 515-530.

11 Д. Соколов, Стихи Александра Анашевича. Два раза [в:] А. Анашевич, Столько ловушек, Москва 1997, с. 33. 
ка» ${ }^{12}$. Гендерная неопределенность, недосказанность, зыбкость собственных телесных границ лирического субъекта коррелирует с зыбкостью географии, традиционно ощущаемой русскоязычными реципиентами в польском культурном ландшафте ${ }^{13}$. Философ и режиссер Кети Чухров, вслед за теоретиком гендерных исследований Джудит Батлер, утверждает:

Не существует какой-то установленной экзистенциальной первичной структуры мужского или женского. Гендер показывает шаткость существования. и попытка находиться в этой неразрешенной, перформативной шаткости и есть собственно гендерная тревога ${ }^{14}$.

В кэмповых перформативных практиках Анашевича тревога и страх, сопровождающие процесс географической трансгрессии, - это зачастую то же самое, что упомянутая гендерная тревога, а шаткость художественного мира компенсируется его нарочитой искусственностью, «судорогами мрачного карнавала» $^{15}$, по выражению Дмитрия Кузьмина. Эстетика средневековых мистерий с бахтиновским смещением телесного низа и верха органически вплетается в пространство Польши, ведь для поэта она (заключенная в тесных рамках между западной Познанью и восточным Краковом: «Только б не стало им холодно, только б не стало им жарко с польскою пулей во лбу, / когда они пересекают земли из Познани в Краков» ${ }^{16}$ [Письмо к Соне Б., которая уехала и не вернулась], «Между Познанью и Краковом лежу, у каждого столба по арабу и персу» ${ }^{17}$ [Где кинжалы твои, где кони...]) - собирательная большая площадь Старого города, на камнях которой можно разыгрывать любые вневременные представления о жизни и смерти: «Если бы меня не выгнали из вагона, увезли в Польшу или / в другую страну, главное, подальше, / в город, где есть огромная площадь, на которой стоит мой балаганчик» ${ }^{18}$ (Я слышал: актер погорелого театра). Подобное понимание - apгумент в пользу того, что квир-культура активно и творчески восприняла советское полонофильство. Несомненны, например, переклички с неокон-

12 А. Кузнецова, Неостановимыцй авангард, «Дружба народов» 2003, № 3, http://magazines. russ.ru/druzhba/2003/3/ku.html (доступ: 1.01.2019).

13 Без всякого сомнения, доминантой Польского текста русской культуры в разные исторические периоды является пороговость, переходная, не совсем ясная и артикулированная роль этого пространства (между Европой и Россией, между Востоком и Западом, между миром живых и мертвых), лиминальность, из которой следуют все дополнительные характеристики, такие как: проницаемость для трансгрессии, экзистенциальный кризис, связанный с процессом пересечения границы, состояние тревоги и страха, маркирующее трансгрессию, специфический «герой перехода» и мифопоэтические коннотации, сопровождающие процесс инициации. Подробнее об этом см.: K. Vorontsova, Польша как граница в послевоенной русской поэзии [в:] Wschód-Zachód w nieprzerwanym dialogu, red. J. Kazimierczyk-Kuncer, Słupsk 2016, c. 131-148.

14 Философ Кети Чухров: «Гендер показывает шаткость существования», https://heoryandpractice.ru/posts/6160-filosof-keti-chukhrov-gender-pokazyvaet-shatkost-sushchestvovaniya (доступ: 1.01.2019).

15 Д. Кузьмин, По поводу «владивостокской школь», «Серая лошадь» 2001, № 4, http://www. gif.ru/greyhorse/crytic/kusmin.html (доступ: 1.01.2019).

16 А. Анашевич, Столько..., ор. cit., с. 24.

17 Ibid., c. 26.

18 Ibid., c. 28. 
ченной поэмой Последние каникулы Давида Самойлова, в которой автобиографический лирический герой путешествует из Кракова в Нюрнберг со скульптором XV века Витом Ствошем, создателем знаменитого алтаря, по средневековой мистериальной Польше. При этом, очевидно, что Нюрнберг недостижим, а герои попали в некую нейтральную полосу «между», выпав из реального пространства-времени: «Как далеко, однако, / преславный городок», «Не близок Нюренберг!», «К Нюренбергу / Две тысячи км» ${ }^{19}$.

Для лирического субъекта поэзии Анашевича Польша - это, в свою очередь, хронотоп привычного и относительно безопасного, так же выключенный из реального исторического времени и существующий в условном Средневековье, соединенном волей автора с Австро-Венгрией периода Первой мировой войны и более современными анахронизмами. Вселенная же вокруг - это хаос: Европа объята войной, а Россия интерпретируется исключительно в качестве засасывающей «бездонной ямы», - в то время как Польша с ее мифопоэтикой вечного перехода ${ }^{20}$ оставляет надежду на загробное существование, вечное блуждание бродячих артистов и попытки (тщетные) ускользнуть от целой галереи смертей: от такой маленькой смерти, что ее видят только лилипуты, до смерти, которая отпрашивается в Петербург искать собственную. Так, Маргарита Меклина в предисловии к книге стихов Фрагменты королевства отмечает «мертвенную „постмортальную” психологичность героев» ${ }^{21}$ Анашевича, с помощью которой в очередной раз утверждается соответствие его творчества паттерну Польского текста.

Танатологическая и патографическая составляющая культурного ландшафта Польши, вместе с традиционной лиминальностью, являются, пожалуй, основой конструирования художественного пространства этой страны в русской литературе: «больная Польша», «умирающая Польша», «Польша - великое кладбище» - концепты, из которых складывается геопоэтика территории, начиная с эпохи романтизма и заканчивая советским периодом ${ }^{22}$. Эта перцепция основана на виктимности описываемой страны из-за трагической истории Разделов, в которой Польша занимала позицию слабой «младшей сестры» по отношению к европейским империям, вершащим ее судьбу. В этом смысле у лирических героев Анашевича много общего с культурным ландшафтом: в творчестве поэта через «тотальное отрицание маскулинности, ассоциируемой исключительно с насилием, позиция жертвы актуализируется как единственно жизнеутверждающая

19 Д. Самойлов, Поэмы, Москва 2005, с. 65, 80, 89.

${ }^{20}$ См.: K. Vorontsova, Poland as a Great Borderland in the Post-Soviet World: Poetical Point of View, "Colloquia Humanistica» 2019, nr 8, c. 142-147.

21 М. Меклина, Пластмассовый король, дама, поэт [в:] А. Анашевич, Фрагменты королевства, Москва 2002, с. 12.

22 Подробнее см.: К.В. Воронцова, Боль и болезнь: антропологические категории художественного пространства Польши в русской поэзии второй половинь ХX века [в:] Восток-Запад: Пространство русской литературы и фольклора, ред. Н. Тропкина, Волгоград 2017, с. 215-223. 
и плодотворная» ${ }^{23}$. Польша в русской культуре традиционно рассматривается в феминных категориях, вбирая в себя и стереотипные представления о прекрасных бесноватых польках-ведьмах, и гордой холодной Марине Мнишек, и чахоточных романтичных паннах. Самое главное, что виктимность как часть женственности в патриархальных сообществах вместе с несгибаемостью под ударами судьбы и некоторым безумием, иррациональностью является естественной причиной для восхищения, которое постоянно ощущается в советской поэзии о Польше. Канонический феминный образ страны в роли бесноватой жертвы, чудом спасающейся на краю неминуемой гибели, находим, например, в заглавном стихотворении полонофилов-шестидесятников Покуда над стихами плачут... Бориса Слуцкого, текст которого знали наизусть и передавали друг другу в первоначальном неподцензурном варианте:

Еще вчера она бежала,

Заламывая руки в страхе,

Еще вчера она лежала

Почти что на десятой плахе.

И вот она романы крутит

И наглым хохотом хохочет.

А то, что было,

То, что будет,-

Про это знать она не хочет ${ }^{24}$.

Глубинное воздействие традиции виктимизации Польши на поэзию Анашевича несомненно.

Особое влияние на творчество поэта оказывает, конечно же, и советский неофициальный дискурс, более раскрепощенный, совсем не подверженный цензуре и самоцензуре. Невозможно отрицать прямые заимствования из текстов Елены Шварц, одной из ключевых фигур ленинградской «второй культуры» и любимейшей поэтессы Анашевича, и особенно из ее большого визионерского стихотворения на польскую тему Плавание $(1975 \text { г. })^{25}$, аллюзией на которое является начало текста Трия: не покидай:

Я, Герман, Георгий, Софья и Серафима

Шли по морю. Польша проплывала мимо

Шли, сердца в кровь стирая, как пилигримы

Шли, как Божьи дети, без одежды и грима... ${ }^{26}$

${ }_{23}$ Д. Кузьмин, «Вдруг мы девочки?»: гендерная проблематика в русской поэзии 1990-х годов. Статья первая, «Новое литературное обозрение» 2018, № 1, https://www.nlobooks.ru/ magazines/novoe_literaturnoe_obozrenie/149_nlo_1_2018/article/19457/?fbclid=IwAR03EDeW bj_eRWcCDnI5Z4eS31iay2k10x-p_sU1W8nPYVQOqTtxеyp7des (доступ: 1.01.2019).

${ }_{24}$ Б.А. Слуцкий, Собрание сочинений в 3-х томах, т. 2, Москва 1991, с. 46.

25 Подробный анализ стихотворения в контексте Польского текста русской литературы см.: K. Woroncowa, Wizja kultury europejskiej w wierszu Jeleny Szwarc Pływanie, «Źródła Humanistyki Europejskiej» 2015, nr 8, c. 91-101.

26 А. Анашевич, Сигналы сирены, Санкт-Петербург 1999, http://www.mitin.com/books/anashevich/ss-1.shtml (доступ: 3.01.2019). 
У Шварц читаем:

Я, Игнаций, Джозеф, Крыся и Маня

В теплой рассохшейся лодке в ослепительном плыли тумане,

Если Висла - залив, то по ней мы, наверно, и плыли,

Были наги - не наги, в клубах розовой пыли... ${ }^{27}$

Отвечая на вопрос о польском происхождении героев этого стихотворения, поэтесса неизменно подчеркивала вдохновляющую мессианскую природу народа-странника, народа-пилигрима (наравне с еврейским и русским народами), которому в духовных поисках доступно значительно больше. Анашевич использует непосредственно слово «пилигрим» (польск. pielgrzym - паломник), репрезентируя метафизические цели путешествия: поиски рая или земли обетованной. Объединяет оба текста и мотив плавания, связанный с однонаправленным процессом трансгрессии из этого мира в иной, загробный, без какой-либо надежды на возвращение: у Шварц Висла, в онейросфере соединенная с Финским заливом, становится Стиксом, который преодолевают уже умершие герои, неспособные вспомнить подробности собственной смерти, в то время как персонажи Анашевича один за одним гибнут в пути, так или иначе приходя к неизбежному концу и пониманию истинной цели паломничества: последнее слово стихотворения - «смерть», которое лирический герой избегает, однако все равно артикулирует - через отрицание.

Что интересно, в художественном мире поэта Польша - часто «морская держава», застигнутая врасплох апокалиптической войной, концом света. Мотив плавания перетекает в мотив бегства по воде, эскапизма от хаоса: «Беглый плывет пароход, идет время./ Мимо Кракова плывет, мимо Риги» ${ }^{28}$ (Шоу); «Проплывал их ковчег между Литвой и Польшей, на обе стороны летели снаряды, палили пушки» ${ }^{29}$ (То, что у Жанны под платьем; то, что у Жанны под кожей) и др. Зыбкость культурного ландшафта, обусловленная более чем вековым отсутствием страны на политических картах мира, продолжает ощущаться и в новейшее время, делая ее не землей, а водой, а следовательно, и наиболее подходящим местом для гендерно неопределенных персонажей поэзии Анашевича.

Нетрудно заметить, что для автора значительным текстопорождающим потенциалом среди прочих польских городов обладает Краков, являющийся квинтэссенцией средневековых лабиринтных структур, разительно отличающихся от прямоты петербургских стрелок и московских проспектов. В художественном мире Анашевича старая королевская столица метонимически является воплощением всей страны: «между россией и польшей, между краковом и москвою / ходила смерть, трогала мое сердце рукою» ${ }^{30}$. Мощеные площади краковского Старого города воспринимаются как островки относительной устойчивости в целом зыбкой страны, и именно они являются

\footnotetext{
27 Е. Шварц, Сочинения Елены Швари. Том І. Стихотворения, Санкт-Петербург 2002, с. 31.

28 А. Анашевич, Сигнальl..., ор. cit.

${ }^{29}$ Idem, Столько..., ор. cit., с. 29.

${ }^{30}$ Idem, Сигнальљ..., op. cit.
} 
функциональным полем для развертывания лирических ситуаций, часто страшных и по-средневековому темных:

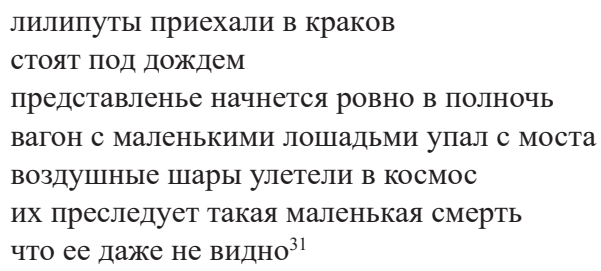

Краков в текстах Анашевича лишен каких-либо романтических коннотаций и намеренно противопоставлен традиционному для советской литературы пониманию города как большого музея под открытым небом с набором устойчивых сигнатур-достопримечательностей. Поэт ничего не описывает, а просто называет, часто со строчной буквы, и это, без сомнения, страшное урбанистическое пространство. Краков - это место встречи лирических персонажей Анашевича со смертью, от которой им удается болееменее успешно ускользать ранее. В наиболее «сгущенном» польском пространстве, обладающем физическими свойствами, происходит встреча с реальностью, принятие судьбы и Grand Finale жизненного шоу переодетых арлекинов, бродячих артистов, «пани аз и пана буки» ${ }^{32}$, солдат и прочих кукол. Среди российских городов подобной функцией наделяется, конечно, Петербург, занимающий центральное место в цикле, названном польские песни, при этом в топографии Северной Венеции Анашевич предельно точен и щепетилен, что дает основания предполагать, во-первых, еще одну референцию в сторону Плавания Елены Шварц, в котором Висла «впадает» в Финский залив, а во-вторых, перцепцию Петербурга как онтологически польского, страшного и призрачного места на ментальных картах русской литературы.

В стихотворении, озаглавленном Петербург, в свою очередь, на нескольких формальных и содержательных уровнях актуализируются польскоеврейские мотивы. Вероятно, текст восходит к библейским Псалмам и является аллюзией на аллюзию, вариацией на вариацию произведения Псалом 3 Генриха Сапгира (на что в определенной мере указывают и отсутствующие в одних и тех же местах знаки препинания), в котором идея эскапизма еврейского народа от врагов, начиная с ветхозаветных времен и заканчивая антисемитизмом XX века, сконцентрирована до предела. Лирический герой аутсайдер, но победитель в перспективе вечности:

\section{1. Господи бегу!}

(...)

Мания

беги беги

$(\ldots)$

$\begin{array}{ll}31 & \text { Ibid. } \\ 32 & \text { Ibid. }\end{array}$ 


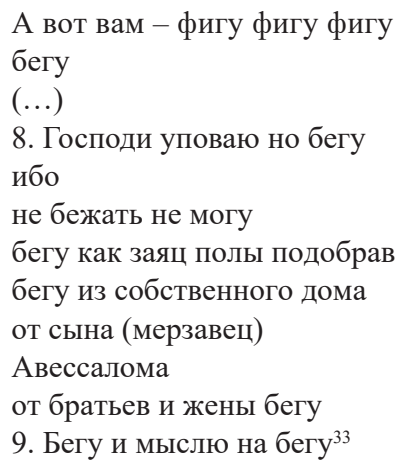

Герой-аутсайдер Анашевича убегает в свою очередь от любви:

Ты меня преследуешь и я бегу бегу, больное сердце согнуто в дугу высушено, похоже на курагу

твоя любовь полная fiction, ведь я шикса ${ }^{34}$

Самоопределение в качестве «шиксы» (традиционно - девушка-нееврейка в отношениях с евреем, либо девушка-еврейка, не соблюдающая нормы ортодоксального иудаизма) - еще одна игра с переодеванием. Автор намеренно избегает личных глагольных форм, оставляя простор для читательского воображения. Отказ от маскулинности и прямого артикулирования гомосексуальности персонажей, гендерная неопределённость демократически маркирует вообще любые формы отношений как «шиксу», если они не предусмотрены религиозной или национальной традицией. На этом фоне гомосексуальность как таковая перестает восприниматься чем-то особенным.

Возлюбленный лирического героя рассматриваемого стихотворения еврей, «польскость» которого воспринимается в качестве основополагающей черты для того, чтобы считаться «ортодоксальным» в современном мире:

ты любишь вуди аллена, его нарисорванные еврейские песни подражаешь ему сутулая спина, невидимые пейсы незаметный польский акцент, тонкие пальцы ${ }^{35}$

По наблюдениям критиков, каждый текст Анашевича - это «маленький спектакль или, учитывая кинематографические аллюзии, короткометражный фильм» ${ }^{36}$.

Возвращаясь к сапгировским Псалмам, необходимо упомянуть и воспринятую оттуда тему Освенцима. Причем у Сапгира этот топоним имплицитен и актуализирован исключительно за счет легко прочитываемого кодифицирующего образа «пепла концлагерей», «дыма из топок» в сочетании

${ }_{33}$ Г. Сапгир, Псалом 3, http://www.ruthenia.ru/60s/lianozovo/sapgir/psalmy/3.htm (доступ: 3.01.2019).

${ }_{34}$ А. Анашевич, Сигналық..., op. cit.

${ }^{35}$ Ibid.

36 А. Урицкий, Остановиться, оглядеться... О книгах Андрея Полякова, Михаила Гронаса, Дмитрия Воденникова, «Дружба народов» 2003, № 9, http://www.litkarta.ru/dossier/uritskiyostanovitsia-ogliadetsia/dossier_2045/ (доступ: 1.01.2019). 
с упоминанием стран, на территории которых в разные времена страдал еврейский народ:

\section{3. Испания Германия \\ Польша Россия \\ Что так жжет босые \\ пятки? \\ Этот пепел \\ еще тепел ${ }^{37}$}

У Анашевича топоним артикулирован и под воздействием механизмов метафоризации, оксюморона и авторской иронии на грани фола лишен каких-либо трагических коннотаций. По сути, топоним, написанный со строчной буквы, - симулякр, который лишь ассоциативно связан с еврейской темой стихотворения и символизирует, как это ни парадоксально, семейные отношения: «люблю свой домашний освенцим, где меня травят словами, жгут перцем» ${ }^{38}$. Танатология Польского текста в данном стихотворении вынесена за скобки.

В отличие от Анашевича, который маскулинность отрицает и стоит на позициях виктимности, поэт, журналист и художник Ярослав Могутин идет от противного и радикально демонстрирует, что его «гомосексуальность впервые победительна, наделена повышенной витальностью. Могутин первый русский гей-писатель, который, собственно, не gay, a queer» ${ }^{39}$. Эпатажность и скандальность «гей-террориста» Могутина - основа его жизнетворчества: он прославился и первой в России попыткой зарегистрировать однополый брак, и своими статьями в «Новой газете», за которые против него было возбуждено два уголовных дела, и вынужденной эмиграцией в США, где ему удалось познакомиться с Алленом Гинсбергом, Деннисом Купером, Франсуа Озоном и другими не менее легендарными фигурами. Его творчество - откровенные интимные дневники, подробно фиксирующие все сексуальные связи и философские размышления о жизни. Могутиным, в отличие от других представителей русскоязычной квир-культуры, движет гипертрофированная гендерная определенность, однако, что интересно, Польша в его стихах появляется в весьма сходных и в определенной мере близких поэзии Анашевича обстоятельствах, что доказывает кодирующую устоявшуюся функцию геокультурного образа страны для всего сообщества. Квир-поэзия репрезентирует одни и те же сценарии снова и снова независимо от авторских установок и интенций.

Показательным в данном случае является стихотворение Ярослава Могутина Латышские каникулы в Польше, в котором полностью отсутствует гендерная неопределенность, однако зыбкость культурного ландшафта (совмещение двух стран в одной точке пространства-времени) обеспечена неопределенностью номинативной: юный лирический герой

${ }^{37}$ Г. Сапгир, op. cit.

38 А. Анашевич, Сигнальл..., ор. cit.

39 Д. Кузьмин, Случай поэта Могутина [в:] Я. Могутин, Упражнения для языка. Стехи о любви и ненависти, New York 1997, с. 157. 
словно не может запомнить имя девушки, к которой обращается: из Ани она становится то Таней, то Леной. По мнению Дмитрия Кузьмина, имена собственные в творчестве поэта лишены дополнительных коннотаций или дневниковости, а лишь заполняют смысловые лакуны. Эксплицитно актуализирована и лиминальная составляющая художественного пространства страны, момент перехода «среди и между», где все действия уже начаты, но еще не закончены: «прибалтика где-то замешкалась / в раздевалках полураздевшись / полуповесившись в вешалках»; «рядом с окном где ты стоишь полуупав / полусвалившись / полувыбросившись» ${ }^{40}$. Перед нами бахтиновский хронотоп порога, в котором происходит экзистенциальный выбор, а в сам момент трансгрессии время замирает. Даже заглавие намекает на эту остановку на пути взросления - каникулы, перерыв, задержка.

Интересно, что неожиданно мягкое и загадочное стихотворение о Польше использует исключительно феминные категории и не содержит эпатажных описаний половых актов, так характерных для поэтики автора, сохраняя лишь намеки на подростковый эротизм. Более того, озвученный геокультурный образ страны вписывается в стереотипное карнавализированное восприятие, рассмотренное нами выше:

мы никогда не будем больше

облизываться языком обходя ногами

берега буйнопомешанной свежепокрашенной

светловолосой польши ${ }^{41}$.

Александр Ильянен - петербургский поэт и романист, лирический герой которого - «кокетливый фланер», в отличие от персонажей Анашевича, иронизирующий над собой и своей подчиненной ролью ${ }^{42}$ и не бунтующий против стереотипов, как это происходит в текстах Могутина. Интеллектуал, военный переводчик с французского, Ильянен интересуется сложными театрально-историческими персонажами, в образах которых культурные мифы переплетаются с реальностью. В данном контексте интересна небольшая поэма МАТА ХАРИ ЭТО Я, посвященная расстрелу знаменитой шпионки-танцовщицы в 1917 году. Собирая образ идеальной женщины в технике коллажа, цитируя русскую и французскую литературу (от Ахматовой до Флобера), Ильянен не может обойти вниманием польских красавиц, со времен Марины Мнишек ассоциирующихся с политической интригой. Воплощением гордой и коварной польки, образ которой «рифмовался бы» с образом Мата Хари, становится Каролина Собаньская:

Мечтала подняться до Каролины Собаньской идеала женщины прошлого века. Быть аристократкой, красавицей, шпионкой, любовницей Пушкина и Мицкевича. Покорить Польшу, Россию и

40 Я. Могутин, Стихи [в:] Вавилон: Вестник молодой литературы, Москва 1997, с. 10.

${ }^{41}$ Ibid.

42 Д. Кузьмин, К русской квир-поэзии: Леденев, Чернышев, Данишевский, 2017, https://syg. ma/@kirill-korchaghin/dmitrii-kuzmin-k-russkoi-kvir-poezii-liedieniov-chiernyshiov-danishievskii (доступ: 4.01.2019). 
Францию43.

Сюжет-миф о романе «солнца русской поэзии» и польской красавицы, пишущей на него доносы, стал культовым в советской поэзии (см.: Яков Белинский, Каролина Собаньская, Белла Ахмадулина, Отрывок из маленькой поэмы о Пушкине). Ильянен, очевидно, воспринимает эту традицию напрямую и рассчитывает на дешифровку культурного кода аудиторией. Собаньская является устойчивым (и именно в официальной советской литературе) парагеографическим понятием, связанным с Польшей. При этом название поэмы может интерпретироваться в категориях гендерной неопределенности и тревоги авторского alter ego. Кто здесь настоящая Мата Хари, смерть которой в финале сравнивается с распятием Христа и гибелью настоящего поэта в высоком смысле слова?

Немного иначе, но в целом оставаясь в рамках заданных культурных практик, создают геокультурное пространство Польши квир-писатели 2000-х. Поэт, прозаик, колумнист «Сноба» и оппозиционный издатель Илья Данишевский - представитель современного «негативного квира», старающийся, по замечанию критиков, «заговорить» ${ }^{44}$ сексуальность своего лирического субъекта, для которого желание составляет онтологические основы бытия. Отсюда следует и поэтика повторений, нагнетание одних и тех же образов, мотивов и конфликтов. Несмотря на то, что основным культурным текстом поэтики автора может считаться «немецкий», Польша находит свое место в его художественной Вселенной, и вновь это пример танатологического пространства перехода. Характерно присутствие сквозного для творчества поэта образа пса, мифопоэтически связанного с загробным миром. В стихотворении-диалоге с умершим возлюбленным Вот мой страх: охранять твой сон... появляется наравне с привычным Данишевскому Берлином и Варшава:

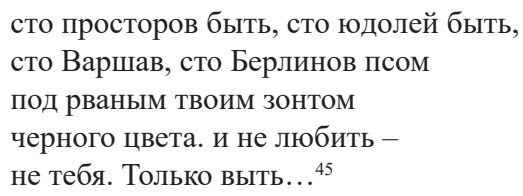

Нетрудно заметить, что пространство воспринимается лирическим героем, для которого после личной трагедии время остановилось, не хорологически, а хронологически, как специфическая форма сублимации. Это больше не конкретный польский топоним, а промежуток времени, который нужно прожить без возлюбленного, граничащий с вечностью: «сто Варшав» могут означать как сто дней, так и целые десятилетия.

Подводя итоги, необходимо заметить, что рассмотренными авторами и текстами проблема интерпретации и репрезентации культурного ланд-

43 А. Ильянен, [Два стихотворения] [в:] Из архива «Новой литературной газеты», Москва 1997, c. 36.

44 Д. Кузьмин, К русской квир-поэзии..., ор. cit.

45 И. Данишевский, Вот мой страх..., https://www.stihi.ru/2012/10/14/633 (доступ: 4.01.2019). 
шафта Польши в квир-поэзии не исчерпывается. Очевидно, что при постепенно затухающем полонофильстве в 90-е и полном отсутствии интереса к стране в 2000-е годы именно квир-культура берет на себя роль посредника между традицией и инновационными подходами к проблеме художественного пространства, находя много общего со стереотипными чертами для русскоязычных реципиентов геокультурных образов Польши и собственными перформативными практиками. Неопределенность, закрепленная в традиции, экзистенциальная мучительная пороговость этого культурного ландшафта перекликается с гендерной неопределенностью квир-поэзии. Это страна неосуществленной до конца трансгрессии, на полпути между одним выбором и другим, именно поэтому она является функциональным полем для встречи со смертью, с самим собой и любовью - опять-таки речь о вполне традиционных испытаниях русской литературы.

\section{Библиография (References)}

Анашевич А., Сигналь сирены, Санкт-Петербург 1999, http://www.mitin.com/ books/anashevich/ss-1.shtml (доступ: 3.01.2019).

Анашевич А., Столько ловушек, Москва 1997.

Вдовин С., Польские мотивы в поэзии Окуджавы, Высоикого, Галича [в:] Окуджава. Проблемь поэтики и текстологии, ред. И. Ришина, Москва 2002.

Воронцова К.В., Боль и болезнь: антропологические категориихудожественного пространства Польши в русской поэзии второй половины XX века [в:] Восток-Запад: Пространство русской литературы и фольклора, ред. Н. Тропкина, Волгоград 2017.

Гарстенауэр Т., Гендерные и квир-исследования в России, «Социология власти» 2018, № 1 .

Данишевский И., Вот мой страх..., https://www.stihi.ru/2012/10/14/633 (доступ: 4.01.2019).

Дарк О., Кальдерон из Воронежа. Из ичикла «Венок портретов современной русской поэзии», «Русский журнал» 2003, http://old.russ.ru/krug/20030616_ od.html (доступ: 1.01.2019).

Ильянен А., [Два стихотворения] [в:] Из архива «Новой литературной газетыл», Москва 1997.

Комлева Н.А., Переформатирование гендера как проявление «мягкой силь»» в геополитических проиессах, “Дискурс-Пи» 2015, № 12.

Кузнецова А., Неостановимый авангард, «Дружба народов» 2003, № 3, http:// magazines.russ.ru/druzhba/2003/3/ku.html (доступ: 1.01.2019).

Кузьмин Д., «Вдруг мы девочки?»: гендерная проблематика в русской поэзии 1990-х годов. Статья первая, «Новое литературное обозрение» 2018, № 1, https://www.nlobooks.ru/magazines/novoe_literaturnoe_obozrenie/149_nlo_1_2018/article/19457/?fbclid=IwAR03EDeWbj_eRWcCDnI5Z4eS31 iay2k10x-p_sU1W8nPYVQOqTtхеур7des (доступ: 1.01.2019).

Кузьмин Д., К русской квир-поэзии: Леденев, Черньшев, Данишевский,2017, https://syg.ma/@kirill-korchaghin/dmitrii-kuzmin-k-russkoi-kvir-poezii-liedieniov-chiernyshiov-danishievskii (доступ: 4.01.2019). 
Кузьмин Д., По поводу «владивостокской школьл», «Серая лошадь» 2001, № 4, http://www.gif.ru/greyhorse/crytic/kusmin.html (доступ: 1.01.2019).

Кузьмин Д., Случай поэта Могутина [в:] Я. Могутин, Упражнения для языка. Стехи о любви и ненависти, New York 1997.

Меклина М., Пластмассовый король, дама, поэт [в:] А. Анашевич, Фрагменть королевства, Москва 2002.

Могутин Я., Стихи [в:] Вавилон: Вестник молодой литературы, Москва 1997.

На перепутье: методология, теория и практика ЛГБТ и квир-исследований, ред. А. Кондаков, Санкт-Петербург 2014.

Самойлов Д., Поэмьl, Москва 2005.

Сапгир Г., Псалом 3, http://www.ruthenia.ru/60s/lianozovo/sapgir/psalmy/3.htm (доступ: 3.01.2019).

Слуцкий Б.А., Собрание сочинений в 3-х томах, т. 2, Москва 1991.

Соколов Д., Стихи Александра Анашевича. Два раза [в:] А. Анашевич, Столько ловушек, Москва 1997.

Урицкий А., Остановиться, оглядеться... О книгах Андрея Полякова, Михаила Гронаса, Дмитрия Воденникова, «Дружба народов» 2003, № 9, http://www.litkarta.ru/dossier/uritskiy-ostanovitsia-ogliadetsia/dossier_2045/ (доступ: 1.01.2019).

Устинкин С.В., Рудакова Е.К., Эминов Д.С., Гендерные стратегии «мягкой силь»» НПО как инструмент переформатирования культурного кода общества и государства в России, «Власть» 2016, № 1 .

Философ Кети Чухров: «Гендер показывает шаткость сущзествования», https:// theoryandpractice.ru/posts/6160-filosof-keti-chukhrov-gender-pokazyvaet-shatkost-sushchestvovaniya (доступ: 1.01.2019).

Хорев В., Польша и поляки глазами русских литераторов, Москва 2004.

Чанцев А., Литература 2.0: Статьи о книгах, Москва 2011.

Шварц Е., Сочинения Елены Швари. Том I. Стихотворения, Санкт-Петербург 2002.

Sontag S., Notes on “Camp”, «Partisan Review» 1964, No. 31.

Vorontsova K., Польский текст в поэзии Бориса Слуцкого: между идеологией и авторской позицией, «Przegląd Rusycystyczny» 2017, nr 3.

Vorontsova K., Польша в поэзии московских концептуалистов: деконструкиия культурных мифов [в:] Wspótczesne badania nad folklorem i literaturą rosyjską: 30 lat toruńskiej rusycystyki, red. B. Żejmo, I. Rzepnikowska, Toruń 2017.

Vorontsova K., Польша как граница в послевоенной русской поэзии [в:] WschódZachód w nieprzerwanym dialogu, red. J. Kazimierczyk-Kuncer, Słupsk 2016.

Vorontsova K., Poland as a Great Borderland in the Post-Soviet World: Poetical Point of View, "Colloquia Humanistica» 2019, nr 8.

Woroncowa K., Wizja kultury europejskiej w wierszu Jeleny Szwarc Pływanie, «Źródła Humanistyki Europejskiej» 2015, nr 8. 


\section{References}

Anashevich A., Signaly sireny, Sankt-Peterburg 1999, http://www.mitin.com/books/ anashevich/ss-1.shtml (access: 3.01.2019).

Anashevich A., Stol'ko lovushek, Moskva 1997.

Vdovin S., Pol'skie motivy v poezii Okudzhavy, Vysockogo, Galicha [v:] Okudzhava. Problemy poetiki i tekstologii, red. I. Rishina, Moskva 2002.

Voroncova K.V., Bol' $i$ bolezn': antropologicheskie kategorii hudozhestvennogo prostranstva Pol'shi v russkoj poezii vtoroj poloviny XX veka [v:] Vostok-Zapad: Prostranstvo russkoj literatury i fol 'klora, red. N. Tropkina, Volgograd 2017.

Garstenauer T., Gendernye i kvir-issledovaniya v Rossii, "Sociologiya vlasti" 2018, nr 1.

Danishevskij I., Vot moj strah..., https:/www.stihi.ru/2012/10/14/633 (access: 4.01.2019).

Dark O., Kal'deron iz Voronezha. Iz cikla "Venok portretov sovremennoj russkoj poezii", "Russkij zhurnal" 2003, http://old.russ.ru/krug/20030616_od.html (access: 1.01.2019).

Il'yanen A., [Dva stihotvoreniya] [v:] Iz arhiva "Novoj literaturnoj gazety", Moskva 1997.

Komleva N.A., Pereformatirovanie gendera kak proyavlenie "myagkoj sily" v geopoliticheskih processah, "Diskurs-Pi” 2015, nr 12.

Kuznecova A., Neostanovimyj avangard, "Druzhba narodov" 2003, nr 3, http://magazines.russ.ru/druzhba/2003/3/ku.html (access: 1.01.2019).

Kuz'min D., "Vdrug my devochki"?: gendernaya problematika v russkoj poezii 1990$h$ godov. Stat'ya pervaya, "Novoe literaturnoe obozrenie" 2018, nr 1, https:// www.nlobooks.ru/magazines/novoe literaturnoe_obozrenie/149_nlo_1_2018/ $\operatorname{article} / 19457 /$ fbclid=IwAR03EDeWbj_eRWcCDnI5Z4eS3 $1 \overline{\text { iay }} \overline{\mathrm{k}} \overline{\mathrm{k}} 10 \mathrm{x}-\mathrm{p}$ sU1W8nPYVQOqTtxeyp7des (access: 1.01.2019).

Kuz'min D., K russkoj kvir-poezii: Ledenev, Chernyshev, Danishevskij, https://syg. ma/@kirill-korchaghin/dmitrii-kuzmin-k-russkoi-kvir-poezii-liedieniov-chiernyshiov-danishievskii (access: 4.01.2019).

Kuz'min D., Po povodu "vladivostokskoj shkoly", "Seraya loshad" 2001, nr 4, http:// www.gif.ru/greyhorse/crytic/kusmin.html (access: 1.01.2019).

Kuz'min D., Sluchaj poeta Mogutina [v:] YA. Mogutin, Uprazhneniya dlya yazyka. stekhi o lyubvi i nenavisti, New York 1997.

Meklina M., Plastmassovyj korol', dama, poet [v:] A. Anashevich, Fragmenty korolevstva, Moskva 2002.

Mogutin Y., Stihi [v:] Vavilon: Vestnik molodoj literatury, Moskva 1997.

Na pereput'e: metodologiya, teoriya $i$ praktika LGBT $i$ kvir-issledovanij, red. A. Kondakov, Sankt-Peterburg 2014.

Sapgir G., Psalom 3, http://www.ruthenia.ru/60s/lianozovo/sapgir/psalmy/3.htm (access: 3.01.2019).

Samojlov D., Poemy, Moskva 2005.

Sluckij B.A., Sobranie sochinenij v 3-h tomah, Moskva 1991, t. 2.

Sokolov D., Stihi Aleksandra Anashevicha. Dva raza [v:] A. Anashevich, Stol'ko lovushek, Moskva 1997.

Shvarc E., Sochineniya Eleny Shvarc. Stihotvoreniya, Sankt-Peterburg 2002. 
Urickij A., Ostanovit'sya, oglyadet'sya... O knigah Andreya Polyakova, Mihaila Gronasa, Dmitriya Vodennikova, "Druzhba narodov" 2003, nr 9, http://www.litkarta. ru/dossier/uritskiy-ostanovitsia-ogliadetsia/dossier_2045/ (access: 1.01.2019).

Ustinkin S.V., Rudakova E.K., Eminov D.S., Gendernye strategii "myagkoj sily" NPO kak instrument pereformatirovaniya kul'turnogo koda obshchestva i gosudarstva v Rossii, "Vlast"” 2016, nr 1.

Filosof Keti Chuhrov: "Gender pokazyvaet shatkost' sushchestvovaniya", https:// theoryandpractice.ru/posts/6160-filosof-keti-chukhrov-gender-pokazyvaet-shatkost-sushchestvovaniya (access: 1.01.2019).

Horev V., Pol'sha i polyaki glazami russkih literatorov, Moskva 2004.

Chancev A., Literatura 2.0: Stat'i o knigah, Moskva 2011.

Sontag S., Notes on “Camp”, „Partisan Review” 1964, nr 31.

Vorontsova K., Pol'sha kak granica v poslevoennoj russkoj poezii [v:] Wschód-Zachód w nieprzerwanym dialogu, red. J. Kazimerczyk-Kuncer, Słupsk 2016.

Vorontsova K., Pol'skij tekst v poezii Borisa Sluckogo: mezhdu ideologij i avtorskoj poziciej „Przegląd Rusycystyczny” 2017, nr 3.

Vorontsova K., Pol'sha v poezii moskovskih konceptualistov: dekonstrukciya kul'turnyh mifov [v:] Współczesne badania nad folklorem i literaturą rosyjską: 30 lat toruńskiej rusycystyki, red. B. Żejmo, I. Rzepnikowska, Torun 2017.

Vorontsova K., Poland as a Great Borderland in the Post-Soviet World: Poetical Point of View, "Colloquia Humanistica" 2019, nr 8.

Woroncowa K. [Vorontsova K.], Wizja kultury europejskiej w wierszu Jeleny Szwarc Plywanie, “Źródła Humanistyki Europejskiej” 2015, nr 8. 